${ }^{8} \mathrm{R}$ Hunter, C Banks and J Giddings, 'Technology is the answer ... what was the question: Services to Regional, Rural and Remote Clients', pl46, in P Pleasence, A Buck, N Balmer, "Transforming Lives: law and social process", Legal Services Commission, 2007.

${ }^{9}$ Roger Smith and Alan Paterson, "Face to Face Legal Services and their Alternatives: Global Lessons from the Digital Revolution", 2014.

${ }^{10}$ National Appropriate Adult Network, "Consultation Response DRAFT - Revised PACE Code C (Detention) 2016 Interpreters", NAAN Policy, 2016 http://appropriateadult.org.uk/images/pdf/2016_CodeC_interpreter_response.pdf (accessed 30th November 2018).

"Louise Tickle, "Online justice: why courts should explore emerging digital possibilities", The Guardian, 16th January 2017 https://www.theguardian.com/public-leaders-network/2017/jan//6/online-justice-courts-explore-digital-possibilities (accessed 29th November 2018).

\title{
Blurred Lines: Social Media in Armed Conflict
}

\section{Winner of the Best in category, Justis International Writing Competition 2019 for the category Social Media, Technology and the Law (in partnership with the Richmond Journal of Law \& Technology), by Iphigenia Fisentzou of BPP.}

Technological advancements have revolutionised the social interactions of global society and in turn influenced the means and methods of warfare; increasing the involvement of civilians in hostilities, not only as victims but also as participants.' Together with the involvement of multiple state and non-state actors, civilian participation makes these modern conflicts all the more unpredictable, challenging inter alia the traditional notion of direct participation in hostilities established under international law.

\section{SOCIAL MEDIA: A MODERN WEAPON}

The first 'internet war' in Kosovo witnessed the utilisation of the internet for the advancement of military operations. $^{2}$ Non-state actors, specifically terrorist organisations, were the first to harness social media networks for the recruitment of followers, the dissemination of information and the gathering of intelligence. ${ }^{3}$ State and inter-state actors have also gradually embraced social media as platforms suited for military operations, ${ }^{4}$ effectively weaponising them through their adaptation and utilisation to 'achieve "military" effects'. ${ }^{5}$

Social networking platforms (Facebook) and microblogging websites (Twitter) are examples of 'social media' enabling social interaction through the creation, collection, sharing and delivery of user-generated content such as photographs and written posts. ${ }^{6}$ Information from social media sites has been used for cyber operations, ${ }^{7}$ as well as for the singling out and targeting of individuals believed to be linked with the opposing parties to a conflict. ${ }^{8}$ "Open source intelligence" has proven instrumental for parties with no boots on the ground of the conflict, 9 
whilst controlling the narrative through the sharing of information on such networks has also become a vital aspect of psychological warfare. ${ }^{10}$

However, the 'weaponisation' of social media can become particularly problematic when undertaken by civilians in a way that it provides military advantages to one of the warring parties.

\section{CVILIANS USING SOCIAL MEDIA: \#DIRECTPARTICIPANTS?}

With more than half of the world's population using the internet, out of which $71 \%$ were active social media users in $2017,1^{\prime \prime}$ it is evident that social media platforms have infiltrated the everyday lives of people around the globe. The line distinguishing civilians from direct participants however becomes blurred when information collected through, and shared on social media by civilians, has real military effects for the conflicting parties.

This challenges the principle of distinction and inevitably results in legal uncertainty as to the applicability of the general protections from attack afforded to civilians under IHL. ${ }^{2}$ Although military powerful states have not ratified all relevant treaties, they are still considered bound due to the rule's customary status. ${ }^{13}$ As the protection of civilians is not absolute, once civilians are considered direct participants in the hostilities, their protection from attack is forfeited, turning them into lawful targets. ${ }^{14}$

The ICRC and NATO sought to bridge the definitional gaps in the legal provisions by providing guidance for their application in both traditional and cyber conflicts. ${ }^{15}$ The ICRC Interpretive Guidance proposed the division of direct participation into three elements: a) threshold of harm, b) direct causation, and c) belligerent nexus, ${ }^{16}$ a tripartite approach also adopted in the Tallinn Manuals. ${ }^{17}$ Whilst the ICRC maintained a restrictive stance to ensure that the protection of civilians as posited by IHL would be guaranteed, NATO was expansive in its interpretation of certain aspects, so as to safeguard military superiority.

Social media platforms could be 'weaponised' by civilians in a number of ways; for example by using Google Maps to identify the coordinates of military objectives and in turn share them on Twitter or Facebook. ${ }^{18}$ Facebook, Twitter and Skype could also be used by civilians for crowdsourcing in order to gather technical knowledge and assist one of the parties to the conflict. ${ }^{19}$ Ultimately, there are certain types of social media activities that can be so harmful to one of the parties to a conflict, ${ }^{20}$ and so direct, ${ }^{21}$ that are capable of triggering the applicability of the direct participation in hostilities principle.

Use of social media networks that can be deemed to satisfy the three-fold test would be sufficient to render a civilian as direct participant in the hostilities, regardless of the temporal and geographical proximity of the act to its eventual effects. Nevertheless, according to the legal provisions, civilians can only be legitimate military targets only 'for such time' as they directly participate in the hostilities. ${ }^{22}$

The exact point when a civilian can be deemed as directly participating in the hostilities depends on a case-bycase analysis of the preparatory measures undertaken before the hostile act. ${ }^{23}$ Considering the relatively limited time period required for a social media activity to be executed, it would seem appropriate that civilians remain direct participants for an amount of time after their engagement, providing therefore a more realistic window of opportunity for the victim or intended victim to react. Maintaining the direct participant status for such time as there can be a reliable causal link between the individual and the hostilities is an appropriate way of dealing with direct participation in the social media context. ${ }^{24}$ The problem that follows however is the lack of a universal understanding as to the meaning of 'reasonable causal link'. Nevertheless, 'each civilian action must be treated separately' 25 even if the perpetrator has repeatedly engaged in hostile acts, since in the context of social media activity, that is often undertaken anonymously, intent to re-engage in such actions can never be accurately presumed.

\section{CONCLUSION}

The lack of a settled approach in determining the applicability of direct participation in hostilities implies that if actors to an armed conflict are adversely affected by hostile civilian acts, they use their own interpretations when applying the IHL provisions, driven by their own motives. Whilst the novelty of social media warfare requires $\mathrm{IHL}$ rules to be applied in a manner flexible enough to meet the complexities of this modern battlefield, the proliferation and widespread use of social media platforms seem to necessitate an adequately reserved interpretation of the rules so as to ensure the protection of civilians. There is a pressing need therefore, for a comprehensive manual to provide guidance to international actors and form the basis for the development of this new controversial area of IHL.

As published in the Richmond Journal of Law \& Technology: Iphigenia Fisetzou, Blurred Lines: Social Media in Armed Conflict, 25 Rich. J.L. \& Tech. 4 (2019).

\section{Footnotes}

'Andreas Wenger, Simon J. A. Mason, 'The civilianization of armed conflict: trends and implications' (2008) 90(872) International Review of the Red Cross 835, 837. 
${ }^{2}$ Thomas Elkjer Nissen, \#TheWeaponizationofSocialMedia: @Characteristics_of_contemporary_conflict (Royal Danish Defence College, 2015) 8.

3 Ibid. 76.

${ }^{4}$ John Pollock, 'People Power 2.0: How civilians helped win the Libyan information war' (MIT Technology Review, 20 April 2012) <https://www.technologyreview.com/s/427640/people-power-20/> accessed 4 April 2018.

${ }^{5}$ Nissen (n.2), 8I-82.

${ }^{6}$ Ibid. 40.

${ }^{7}$ Nissen (n.2), 30. Josh Constine 'ISIS “Cyber Caliphate” Hacks U.S. Military Command Accounts' (TechCrunch.com, 12 January 2015) <https://techcrunch.com/2015/0I//2/cyber-caliphate/?guccounter=1> accessed 10 June 2018; Armin Rosen, 'A self-proclaimed ISIS fan is hacking local news outlets', (Business Insider, 6 January 2015) <http://www.businessinsider.com/ a-self-proclaimed-isis-fan-is-hacking-local-news-outlets-2015-1> accessed 10 June 2018.

8 Ibid., 82. John Brown, 'Opinion Arrest of Palestinians for Potential Terror Attacks Brings New Meaning to 'Minority Report' (Haaretz.com, 24 April 2017) <https://www.haaretz.com/opinion/.premium-arrest-of-palestinians-brings-new-meaning-to-minority-report-1.5464664> accessed 25 May 2018.

${ }^{9}$ Pollock (n.4), 68.

${ }^{10}$ Nissen (n.2) at 84. James P. Farwell, 'The Media Strategy of ISIS' (20I4) 56(6) Survival 49, 52. Chris Zambelis, 'Information Wars: Assessing the Social Media Battlefield in Syria' (2012) 5(7) CTS Sentinel 19. J.M. Berger, 'How ISIS Games Twitter' (The Atlantic.com, 16 June 2014) <https:/www.theatlantic.com/international/archive/2014/06/isis-iraq-twitter-social-media-strategy/ $372856 />$ accessed 30 May 2018.

11 'Global digital population as of April 2018 (in millions)' (Statista.com, 2018) <https://www.statista.com/statistics/617/36/digitalpopulation-worldwide/> accessed 10 June 2018; 'Number of social media users worldwide from 2010 to 2021 (in billions)' (Statista.com, 2018) <https://www.statista.com/statistics/2784/4/number-of-worldwide-social-network-users/> accessed 10 June 2018.

${ }^{12}$ Geneva Convention for the amelioration of the condition of the wounded and sick in armed forces in the field (adopted 12 August 1949, entered into force 21 October 1950) 75 UNTS 31; Geneva Convention for the amelioration of the condition of the wounded, sick and shipwrecked members of the armed forces at sea (adopted 12 August 1949, entered into force 21 October 1950) 75 UNTS 85; Geneva Convention relative to the treatment of prisoners of war (adopted 12 August 1949 , entered into force 21 October 1950) 75 UNTS 135; Geneva Convention relative to the protection of civilian persons in time of war (adopted 12 August 1949, entered into force 21 October 1950) 75 UNTS 287. Protocol Additional to the Geneva Conventions of 12 August 1949, and relating to the Protection of Victims of International Armed Conflicts (adopted 8 June 1977, entered into force 7 December 1978) II 25 UNTS 3 (Additional Protocol I); Protocol Additional to the Geneva Conventions of 12 August 1949 and relating to the protection of victims of non-international armed conflicts (adopted 8 June 1977, entered into force 7 December 1978) II25 UNTS 609 (Additional Protocol II); Protocol additional to the Geneva Conventions of 12 August 1949, and relating to the adoption of an additional distinctive emblem (adopted 8 December 2005, entered into force 15 January 2007) 2404 UNTS 26 I (Additional Protocol III).

${ }^{13}$ Legality of the Threat or Use of Nuclear Weapons, Advisory Opinion (Advisory Opinion) [1996] IC] Rep 226, 257.

${ }^{14}$ Michael N. Schmitt, 'Deconstructing Direct Participation in Hostilities: The Constitutive Elements' (2010) 42 N.Y.U. Journal of International Law and Politics 697, 698 footnote 2.

${ }^{15}$ Nils Melzer, Interpretive Guidance on the Notion of Direct Participation in Hostilities under International Humanitarian Law (ICRC 2009) 44. Michael N. Schmitt ed., Tallinn Manual on the International Law Applicable to Cyber Warfare (Cambridge University Press 2013). Michael N. Schmitt ed., Tallinn Manual 2.0 on the International Law Applicable to Cyber Operations (Cambridge University Press 2017).

${ }^{16}$ ICRC Interpretive Guidance (n. I5), 46.

${ }^{17}$ Collin Allan, 'Direct Participation in Hostilities from Cyberspace' (2013) 54 Virginia Journal of International Law 173 , 176.

${ }^{18}$ Although not a traditional social media site, the author contents that for the context of this paper and in light of the recent 'share' options added to the website, Google Maps falls under the social media category.

${ }^{19}$ Pollock (n.4), 63.

${ }^{20}$ ICRC Interpretive Guidance (n. I5), 48.

${ }^{21}$ ICRC Interpretive Guidance (n. I5), 5I-53.

${ }^{22}$ Additional Protocol I (n. I2), art. 5 I (3); Additional Protocol II (n. I I) art. I3(3).

${ }^{23}$ ICRC Interpretive Guidance (n. I5), 65-70.

${ }^{24}$ Tallinn Manual (n. I5), 121.

${ }^{25}$ Allan (n. 17), 192. 